\title{
Effect of Bion and Amistar in inducing resistance against Cercospora leaf spot of banana
}

\author{
Fahmida Akter, Md. Mijanur Rahman Mejan, Mst. Arjina Akter and ${ }^{\circledR}$ Ismail Hossain
}

Department of Plant Pathology, Faculty of Agriculture, Bangladesh Agricultural University, Mymensingh-2202, Bangladesh

\begin{tabular}{|c|c|}
\hline ARTICLE INFO open ${ }_{\text {access }}$ & Abstract \\
\hline $\begin{array}{l}\text { Article history: } \\
\text { Received: 04 July } 2018 \\
\text { Accepted: 08 December } 2018 \\
\text { Published: } 31 \text { December } 2018\end{array}$ & \multirow{3}{*}{$\begin{array}{l}\text { Bion (benzothiadiazole) and Amistar (azoxystrobin) were applied for controlling Cercospora leaf spot of } \\
\text { banana variety Amrita Sagarin at the field laboratory, Department of Plant Pathology, Bangladesh } \\
\text { Agricultural University (BAU), Mymensingh by applying different treatments viz. dipping bottom of } \\
\text { sucker for } 6 \text { hrs. in Bion (0.005\%) before planting, dipping bottom of sucker for } 6 \text { hrs. in Bion }(0.01 \%) \\
\text { before planting, spraying of Bion @ } 0.005 \% \text { once on leaves after } 80 \text { days of planting, spraying of Bion @ } \\
0.01 \% \text { once on leaves after } 80 \text { days of planting, spraying of Amistar @ } 0.05 \% \text { once on leaves after } 80 \\
\text { days of planting, spraying of Amistar @ } 0.05 \% \text { only on leaves after } 80 \text { and } 140 \text { days of planting, spraying } \\
\text { of Bion @ } 0.005 \% \text { ) once on leaves and pseudostem after } 80 \text { days of planting, spraying of Bion @ } 0.01 \% \\
\text { once on leaves and pseudostem after } 80 \text { days of planting and control (without chemical). From these } \\
\text { above treatments it is revealed that dipping of bottom of banana sucker for } 6 \text { hrs. in Bion either @ } 0.005 \% \\
\text { or } 0.01 \% \text { significantly reduced plant height, while Bion and Amistar did not exert any effect on number of } \\
\text { leaf/ plant. Bion @ } 0.005 \% \text { and } 0.01 \% \text { (dipping of bottom of sucker before planting), Bion @ } 0.01 \% \text { (on } \\
\text { leaves, 1 spray) and } 0.01 \% \text { (on leaves and pseudostem, } 1 \text { spray) and Amistar @ 0.05\% (on leaves, } 2 \\
\text { spray) showed significant effect in reducing number of diseased leaf/ plant, number of diseased spot/ } \\
\text { plant, percent leaf area }\left(\mathrm{cm}^{2}\right) \text { diseased/ plant, mean spot size }\left(\mathrm{mm}^{2}\right) / \text { plant of banana var. Amrita sagar. }\end{array}$} \\
\hline $\begin{array}{l}\text { Keywords: } \\
\text { Banana; Induce Resistance; Leaf } \\
\text { spot; Bion, Amistar }\end{array}$ & \\
\hline 凶: dhossain69@gmail.com & \\
\hline
\end{tabular}

Copyright:

(c) (i)

(O2018 by authors and BAURES. This work is licensed under the Creative Commons Attribution International License (CC By 4.0).

\section{Introduction}

Bananas (Musa spp. L.) are monocotyledonous plants that belong to the family Musaceae and it is one of the most important fruits in the world and is widely grown in the tropical and sub-tropical countries the genus Musa originated in Southeast Asia (Khan et. al, 2015). Banana is one of the most important tropical fruit crops of the world (Thammaiah and Shirol, 2013). Bangladesh produces nearly 1.0 million tons of bananas annually (Hossain, 2014). The fruit of banana is an inexhaustible source of vitamins, minerals and carbohydrates that essential for human nutrition. One hundred grams edible portion of banana contain $27.0 \%$ carbohydrate, $1.2 \%$ protein, $0.3 \%$ fat, $290.0 \mathrm{ppm}$ phosphorus, $80.0 \mathrm{ppm}$ calcium, $6.0 \mathrm{ppm}$ iron, $0.5 \mathrm{ppm} 13$-carotene, $0.5 \mathrm{ppm}$ riboflavin, $7.0 \mathrm{ppm}$ niacin and $120.0 \mathrm{ppm}$ ascorbic acid (Anon, 1976). In Bangladesh, the yield of this crop is only $14.55 \mathrm{t} / \mathrm{ha}$, which is too low as compared to the developed countries of the world (FAO, 2001). There are many constraints responsible for low yield of banana in Bangladesh of which diseases have been considered as one of the major factor. Cercospora leaf spot (sigatoka) of banana is a serious and common disease in Bangladesh. In severe infection of banana plant, the whole plant may die or even it cannot bear fruits. Sometimes it causes $50 \%$ yield loss. It reduces the yield of banana by reducing the photosynthesis of banana plant (Hossain et. al, 2017).Control of this disease by chemicals is difficult, speciallyduring the rainy season. Moreover, use of chemicals in fruits has a bad impact on health. Use of plant inducer or resistance activator is a recent approach to plant disease management and it has drawn the special attention of the plant pathologist all over the world. Inducing resistance against the disease can be considered as an alternative to use frequent chemicals and less hazardous to nature. The banana disease may be minimized or controlled through inducing resistance in plant. Bion $50 \mathrm{WG}$ copies this natural biological phenomenon and provides reliable and commercially acceptable protection in several crops against a number of diseases (Janczak and Bielecki, 1997). It is a novel plant protection product that mimics the host-pathogen interaction and results in systemic acquired resistance in plants (Cole, 1999). Inducing resistance is a new concept in Bangladesh and attempt had been made to use chemicals as resistance inducer to banana. The study was undertaken to evaluate Bion and Amisterin inducing resistance to banana plant against Cercospora (sigatoka) leaf spot.

\section{Materials and Methods}

The experiment was carried out in the field laboratory, Department of Plant Pathology, Bangladesh Agricultural University (BAU), Mymensingh, Bangladesh.Sword suckers of banana variety viz.Amrita Sagarwere collected from Boira union, Sadarupazilla, Mymensingh, Bangladesh. Three weeks before planting, pits of $0.60 \mathrm{~m}$ diameter and $0.40 \mathrm{~m}$ depth were prepared by digging the soil with spade (Haque, 1988). After one week of pit preparation with manures and fertilizers, uniform sized 
selected rhizomes of banana variety viz. The rhizome in a pit was covered by about $10 \mathrm{~cm}$ soil and the soil around it was pressed firmly. There were two chemicals namely Bion (benzothiadiazole), an inducer of resistance and Amistar (azoxystrobin), a fungicide was used in this experiment. The treatments were: $\mathrm{T}_{1}=$ Dipping bottom of sucker for $6 \mathrm{hrs}$ in Bion (0.005\%) before planting, $\mathrm{T}_{2}$ $=$ Dipping bottom of sucker for $6 \mathrm{hrs}$ in Bion $(0.01 \%)$ before planting, $\mathrm{T}_{3}=$ Spraying Bion $(0.005 \%)$ once only on leaves after 80 days of planting, $\mathrm{T}_{4}=$ Spraying Bion $(0.01 \%)$ once only on leaves after 80 days of planting, $\mathrm{T}_{5}=$ Spraying Amistar $(0.05 \%)$ once only on leaves after 80 days of planting, $\mathrm{T}_{6}=$ Spraying Amistar $(0.05 \%)$ only on leaves after 80 and 140 days of planting, $\mathrm{T}_{7}=$ Spraying Bion (0.005\%) once on leaves and pseudo stem after 80 days of planting, $\mathrm{T}_{8}=$ Spraying Bion $(0.01 \%)$ once on leaves and pseudo stem after 80 days of planting andT $_{9}=$ Control (without chemical). Each spray solution was prepared by mixing definite amount of chemicals with tap water and the bottom of suckers carefully treated. In case of single spray, Amistar $(0.05 \%)$, Bion $(0.005 \%$ and $0.01 \%)$ were sprayed at 80 days after planting. The second spray of Amistar (0.05\%) was done at 140 days after planting. The experimental plots were inspected at 15 days interval for the appearance of Cercospora (sigatoka) leaf spot. The data on the following parameters were considered for collection: i). Plant height $(\mathrm{cm})$, ii). Number of leaves per plant, iii) Number of sucker per plant, iv) Healthy and diseased sucker per plant, v) Percent leaf area diseased per sucker, vi) Mean spot size per main plant. The experiment was carried out in Randomized Completely BlockDesign (RCBD) with three replications. Eachreplication contains four banana plants.

\section{Results and Discussion}

The effect of Bion and Amistar on plant height $(\mathrm{cm})$ of banana var. Amrita Sagar was varied significantly among differen treatments (Table 1). The highest plant height $(148.00 \mathrm{~cm})$ was recorded in $\mathrm{T}_{6}$ at $240 \mathrm{DAP}$ and the lowest $(7.50 \mathrm{~cm})$ in $\mathrm{T}_{2}$ at $60 \mathrm{DAP}$. The effect of Bion and Amistar on number of leaf per plant of banana var. Amrita Sagar was also found significant among the treatment (Table 2). The highest number of leaves /plant (14.00) were recorded in $\mathrm{T}_{4}$ and $\mathrm{T}_{6}$ at 240 DAP and the lowest (5.50) in $\mathrm{T}_{1}$ and $\mathrm{T}_{2}$ at $60 \mathrm{DAP}$.

Table 1. Effect of Bion and Amistar on plant height of banana var. Amrita Sagar

\begin{tabular}{rrrrrrrr}
\hline \multirow{2}{*}{ Treatments } & \multicolumn{7}{c}{ Plant height $(\mathrm{cm})$} \\
\cline { 2 - 8 } & $60 \mathrm{DAP}$ & $90 \mathrm{DAP}$ & \multicolumn{1}{c}{$120 \mathrm{DAP}$} & $150 \mathrm{DAP}$ & $180 \mathrm{DAP}$ & $210 \mathrm{DAP}$ & $240 \mathrm{DAP}$ \\
\hline $\mathrm{T}$ & $11.00 \mathrm{j}$ & 20.001 & $35.50 \mathrm{~h}$ & $52.00 \mathrm{de}$ & $66.00 \mathrm{de}$ & $78.50 \mathrm{~b}-\mathrm{d}$ & $119.00 \mathrm{de}$ \\
$\mathrm{T} 2$ & $7.50 \mathrm{k}$ & $15.50 \mathrm{j}$ & $19.50 \mathrm{i}$ & $38.00 \mathrm{f}$ & $46.00 \mathrm{f}$ & $69.50 \mathrm{~d}$ & $98.00 \mathrm{e}$ \\
$\mathrm{T} 3$ & $24.00 \mathrm{f}$ & $38.00 \mathrm{f}$ & $47.50 \mathrm{ef}$ & $59.50 \mathrm{~b}-\mathrm{e}$ & $74.00 \mathrm{~b}-\mathrm{e}$ & $89.00 \mathrm{a}-\mathrm{c}$ & $131.50 \mathrm{a}-\mathrm{d}$ \\
$\mathrm{T} 4$ & $32.00 \mathrm{bc}$ & $39.50 \mathrm{ef}$ & $48.50 \mathrm{e}$ & $57.50 \mathrm{c}-\mathrm{e}$ & $66.00 \mathrm{de}$ & $93.50 \mathrm{ab}$ & $146.00 \mathrm{a}-\mathrm{c}$ \\
$\mathrm{T} 5$ & $17.00 \mathrm{~h} . \mathrm{i}$ & $27.50 \mathrm{~h}$ & $43.5 \mathrm{Ofg}$ & $57.00 \mathrm{c}-\mathrm{e}$ & $70.00 \mathrm{c}-\mathrm{e}$ & $87.50 \mathrm{a}-\mathrm{d}$ & $132.50 \mathrm{a}-\mathrm{d}$ \\
$\mathrm{T}_{6}$ & $29.50 \mathrm{~cd}$ & $46.00 \mathrm{bc}$ & $63.00 \mathrm{a}$ & $77.00 \mathrm{a}$ & $94.00 \mathrm{a}$ & $100.00 \mathrm{a}$ & $148.00 \mathrm{ab}$ \\
$\mathrm{T}_{7}$ & $20.50 \mathrm{~g}$ & $32.00 \mathrm{~g}$ & $46.50 \mathrm{ef}$ & $58.5 . \mathrm{b}-\mathrm{e}$ & $73.00 \mathrm{~b}-\mathrm{e}$ & $82.50 \mathrm{a}-\mathrm{d}$ & $137.50 \mathrm{a}-\mathrm{d}$ \\
$\mathrm{T}_{8}$ & $27.50 \mathrm{de}$ & $44.50 \mathrm{~cd}$ & $57.50 \mathrm{bcI}$ & $69.50 \mathrm{a}-\mathrm{c}$ & $80.50 \mathrm{bc}$ & $90.50 \mathrm{ab}$ & $130.50 \mathrm{~b}-\mathrm{d}$ \\
$\mathrm{T} 9$ & 15.001 & $25.00 \mathrm{~h}$ & $41.00 \mathrm{~g}$ & $54.00 \mathrm{de}$ & $67.50 \mathrm{c}-\mathrm{e}$ & $82.50 \mathrm{a}-\mathrm{d}$ & $134.00 \mathrm{a}-\mathrm{d}$ \\
$\mathrm{T}$ & 5.99 & $11.00 \mathrm{j}$ & 20.001 & $35.50 \mathrm{~h}$ & $66.00 \mathrm{de}$ & $78.50 \mathrm{~b}-\mathrm{d}$ & $119.00 \mathrm{de}$ \\
${ }^{1} \mathrm{LV}(\%)$ & 2.993 & $7.50 \mathrm{k}$ & $15.50 \mathrm{j}$ & $19.50 \mathrm{i}$ & $46.00 \mathrm{f}$ & $69.50 \mathrm{~d}$ & $98.00 \mathrm{e}$ \\
\hline
\end{tabular}

Table 2. Effect of Bion and Amistar on number of leaf per plant of banana var. Amrita sagar

\begin{tabular}{rlcccccc}
\hline \multirow{2}{*}{ Treatments } & \multicolumn{7}{c}{ Number of leaf per plant } \\
\cline { 2 - 7 } & $60 \mathrm{DAP}$ & $90 \mathrm{DAP}$ & $120 \mathrm{DAP}$ & $150 \mathrm{DAP}$ & $180 \mathrm{DAP}$ & $210 \mathrm{DAP}$ & $240 \mathrm{DAP}$ \\
\hline $\mathrm{T}_{1}$ & $5.50 \mathrm{de}$ & $8.50 \mathrm{c}-\mathrm{f}$ & $9.00 \mathrm{ab}$ & $10.00 \mathrm{a}$ & $11.00 \mathrm{a}$ & $11.00 \mathrm{a}$ & $12.00 \mathrm{a}-\mathrm{c}$ \\
$\mathrm{T}_{2}$ & $5.50 \mathrm{de}$ & $6.50 \mathrm{~g}$ & $7.50 \mathrm{~b}$ & $8.50 \mathrm{a}$ & $9.50 \mathrm{a}$ & $9.50 \mathrm{ab}$ & $10.50 \mathrm{bc}$ \\
$\mathrm{T}_{3}$ & $8.00 \mathrm{ab}$ & $9.50 \mathrm{~cd}$ & $9.50 \mathrm{ab}$ & $10.50 \mathrm{a}$ & $10.50 \mathrm{a}$ & $12.50 \mathrm{a}$ & $11.00 \mathrm{a}-\mathrm{c}$ \\
$\mathrm{T}_{4}$ & $8.00 \mathrm{ab}$ & $10.00 \mathrm{bc}$ & $10.00 \mathrm{ab}$ & $10.50 \mathrm{a}$ & $11.00 \mathrm{a}$ & $11.50 \mathrm{a}$ & $14.00 \mathrm{a}$ \\
$\mathrm{T}_{5}$ & $7.50 \mathrm{bc}$ & $9.00 \mathrm{c}-\mathrm{e}$ & $9.50 \mathrm{ab}$ & $10.00 \mathrm{a}$ & $11.50 \mathrm{a}$ & $11.50 \mathrm{a}$ & $13.00 \mathrm{ab}$ \\
$\mathrm{T}_{6}$ & $9.00 \mathrm{a}$ & $12.00 \mathrm{a}$ & $11.00 \mathrm{a}$ & $11.00 \mathrm{a}$ & $11.00 \mathrm{a}$ & $11.00 \mathrm{a}$ & $14.00 \mathrm{a}$ \\
$\mathrm{T} 7$ & $6.50 \mathrm{~cd}$ & $9.00 \mathrm{c}-\mathrm{e}$ & $9.50 \mathrm{ab}$ & $10.50 \mathrm{a}$ & $11.50 \mathrm{a}$ & $11.50 \mathrm{a}$ & $13.00 \mathrm{ab}$ \\
$\mathrm{T} 8$ & $8.50 \mathrm{ab}$ & $11.50 \mathrm{ab}$ & $11.00 \mathrm{~b}$ & $11.50 \mathrm{a}$ & $11.00 \mathrm{a}$ & $10.50 \mathrm{a}$ & $11.50 \mathrm{a}-\mathrm{c}$ \\
$\mathrm{T}_{9}$ & $7.50 \mathrm{bc}$ & $9.00 \mathrm{c}-\mathrm{e}$ & $9.00 \mathrm{ab}$ & $9.50 \mathrm{a}$ & $10.50 \mathrm{a}$ & $12.00 \mathrm{a}$ & $13.50 \mathrm{ab}$ \\
$\mathrm{LSD}_{(\mathrm{p}}>_{0.05)}$ & 1.092 & 1.714 & 2.244 & 2.894 & 2.894 & 2.814 & 2.860 \\
\hline
\end{tabular}

DAP = Days after planting, $\mathrm{T}_{1}=$ Dipping bottom of sucker for $6 \mathrm{hrs}$ in Bion $(0.005 \%)$ before planting, $\mathrm{T}_{2}=$ Dipping bottom of sucker for $6 \mathrm{hrs}$ in Bion $(0.01 \%)$ before planting, $\mathrm{T}_{3}=$ Spraying Bion $(0.005 \%)$ once on leaves after 80 days of planting, $\mathrm{T}_{4}=$ Spraying Bion $(0.01 \%)$ once on leaves after 80 days of planting, $\mathrm{T}_{5}=$ Spraying Amistar $(0.05 \%)$ once on leaves after 80 days of planting, $\mathrm{T}_{6}=$ Spraying Amistar $(0.05 \%)$ on leaves after 80 and 140 days ofplanting, $\mathrm{T}_{7}=$ Spraying Bion $(0.005 \%)$ once on leaves and pseudostem after 80 days of planting. $\mathrm{T}_{8}=$ Spraying Bion $(0.01 \%)$ once on leaves and pseudostem after 80 days of planting. $\mathrm{T}_{9}=$ Control (without chemical) 
The effect of Bion and Amistar on number of sucker per plant of banana variety Amrita Sagar was determined at 120, 150, 180, 210 and 240 days after planting (DAP) and presented in Fig. 1. The treatments showed significant influence on number of sucker per plant at different days after planting. The highest number of sucker per plant (7.0) was found in $\mathrm{T}_{6}$ at $240 \mathrm{DAP}$ and sucker was not found in $\mathrm{T}_{1}, \mathrm{~T}_{2}, \mathrm{~T}_{5}, \mathrm{~T}_{8}$. The lowest number of sucker per plant (0.5) was found in $\mathrm{T}_{4}, \mathrm{~T}_{7}, \mathrm{~T}_{9}$ at 120 and 150 DAP. The effect of Bion and Amistar on healthy sucker per plant of banana variety Amrita Sagar was determined at 170, 185, 200, 215 and 230 days after planting (DAP) and presented in Fig. 2. The treatments showed significant influence on healthy and diseased sucker per plant at different days after planting. The highest number of healthy sucker per plant (6.0) was found in $\mathrm{T}_{6}$ at $230 \mathrm{DAP}$ (Fig. 2). The effect of Bion and Amistar on diseased sucker per plant of banana variety AmritaSagar was determined at 170, 185, 200, 215 and 230 days after planting (DAP) and presented in Fig. 3. The highest diseased sucker (3.0) was found in $\mathrm{T}_{9}$ (control) at $230 \mathrm{DAP}$ and the lowest number of diseased sucker (0.5) was found also inT 9 (control) at $170 \mathrm{DAP}$.
The effect of Bion and Amistar on percent leaf area diseased per sucker of banana variety Amrita Sagar was determined at 170, 185, 200, 215 and 230 days after planting (DAP) and presented in Fig. 4. The treatments showed significant influence on percent leaf area diseased per sucker of banana at different days after planting. At 230 DAP, the highest percent leaf area diseased (1.79) was found in T9 (control) plant and leaf area diseased was not found in $\mathrm{T}_{1}, \mathrm{~T}_{2}, \mathrm{~T}_{4}$ and $\mathrm{T}_{8}$. The effect of Bion and Amistar on mean spot size per plant $\left(\mathrm{mm}^{2}\right)$ of banana variety Amrita Sagar was determined at $150,165,180,195,210,225$ and 240 days after planting (DAP) and presented in Fig. 5. The treatments showed significant influence on mean spot size per plant $\left(\mathrm{mm}^{2}\right)$ of banana var. Amrita Sagar at different days after planting. The highest mean spot size per plant (56.7 $\mathrm{mm}^{2}$ ) was found in $\mathrm{T}_{9}$ (control) plant at $240 \mathrm{DAP}$ and the lowest size of Sigatoka spot $\left(1.0 \mathrm{~mm}^{2}\right) \mathrm{T}_{7}$ at210 DAP.

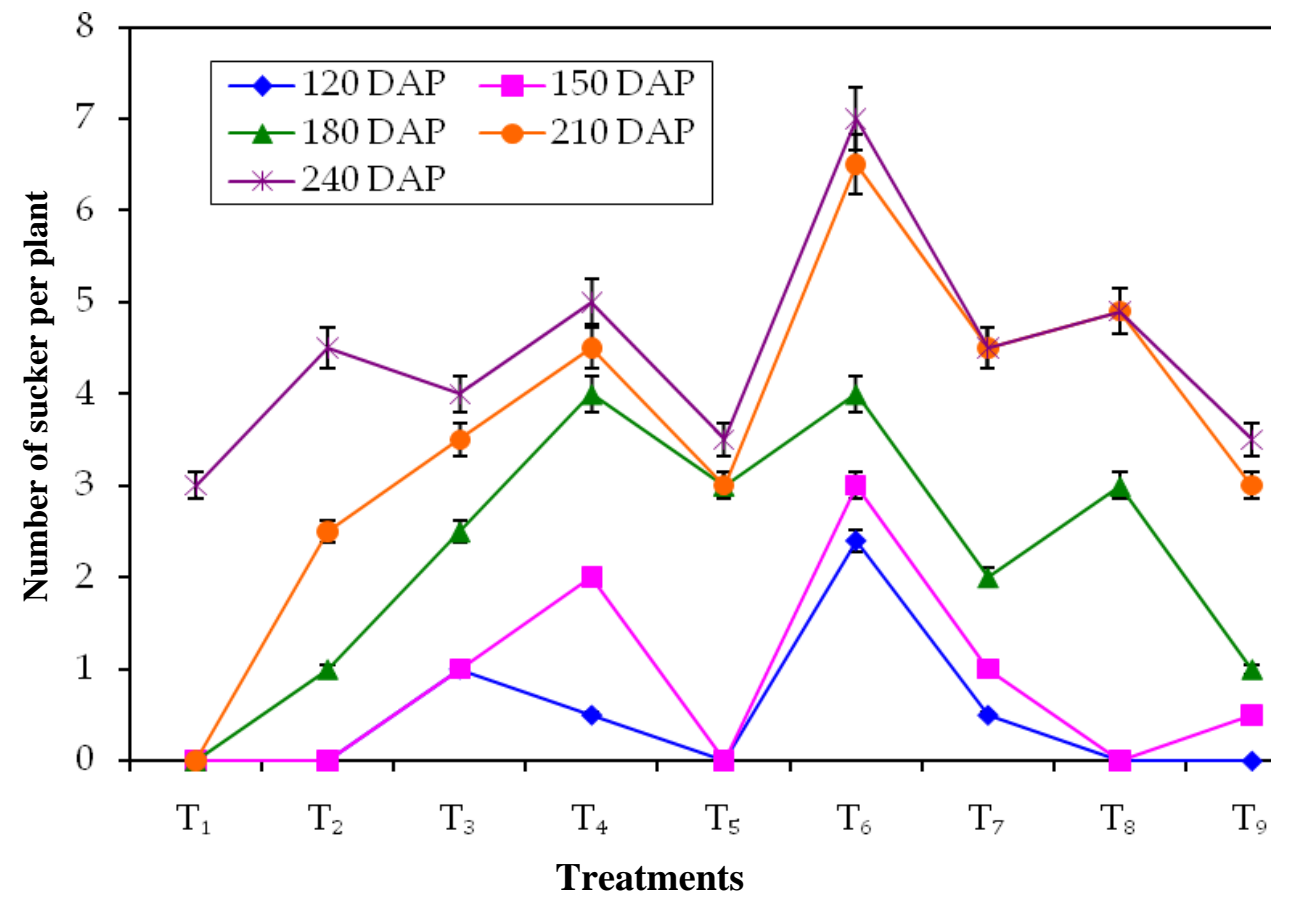

Fig.1. Effect of Bion and Amistar on number of sucker per plant of banana var. Amrita Sagar at different days after planting

DAP $=$ Days after planting

$\mathrm{T}_{1}=$ Dipping bottom of sucker for $6 \mathrm{hrs}$ in Bion $(0.005 \%)$ before planting, $\mathrm{T}_{2}=$ Dipping bottom of sucker for $6 \mathrm{hrs}$ in Bion $(0.01 \%)$ beforeplanting, $\mathrm{T}_{3}=$ Spraying Bion $(0.005 \%)$ once on leaves after 80 days of planting, $\mathrm{T}_{4}=$ Spraying Bion $(0.01 \%)$ once on leaves after 80 days of planting, $\mathrm{T}_{5}=$ Spraying Amistar $(0.05 \%)$ once on leaves after 80 days of planting, $\mathrm{T}_{6}=$ Spraying Amistar $(0.05 \%)$ once on leaves after 80 and 140 days of planting, $\mathrm{T}_{7}=$ Spraying Bion $(0.005 \%)$ once on leaves and pseudostem after 80 days of planting, $\mathrm{T}_{8}=$ Spraying Bion $(0.01 \%)$ once on leaves and pseudostem after 80 days of planting, $\mathrm{T}_{9}=\mathrm{Control}$ (without chemical) 


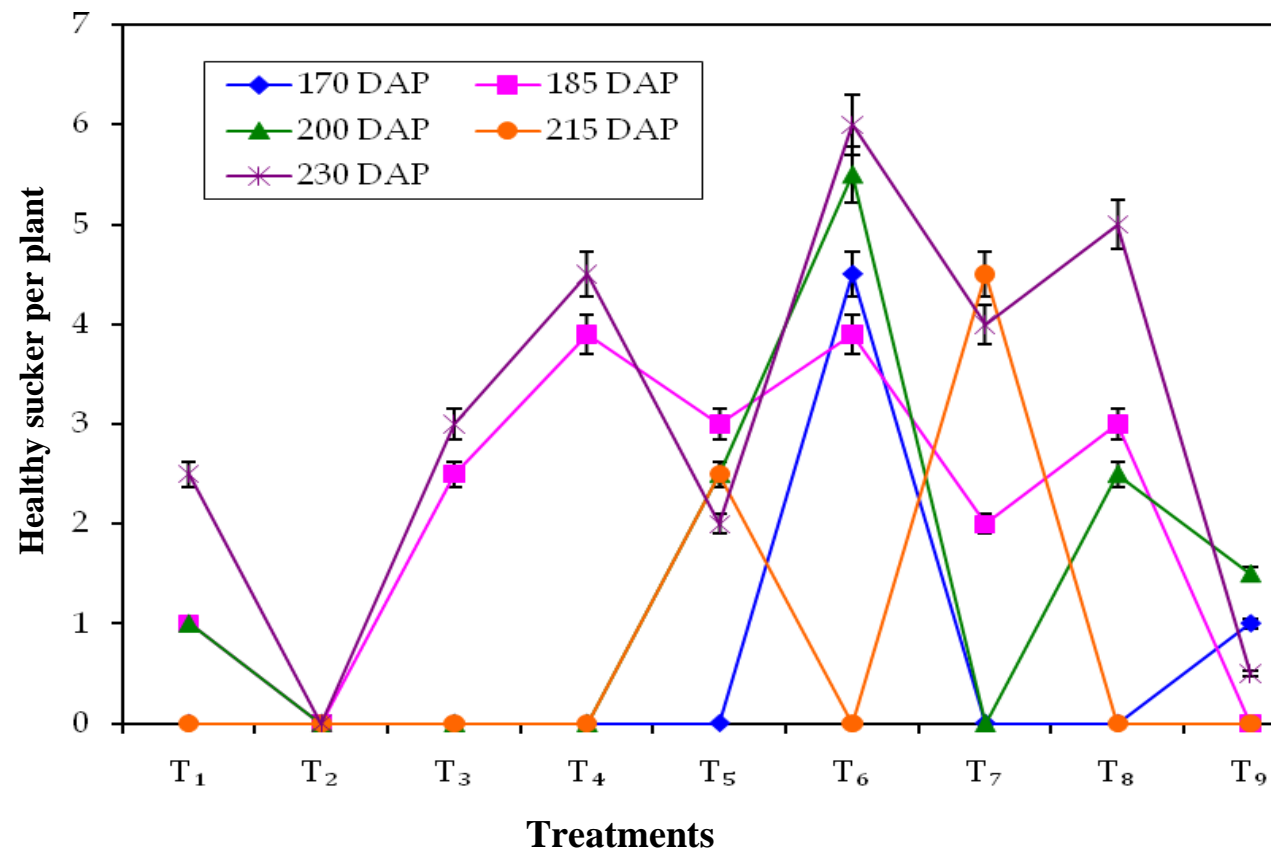

Fig. 2. Effect of Bion and Amistar on healthy sucker per plant of banana var. Amrita Sagar at different days after planting

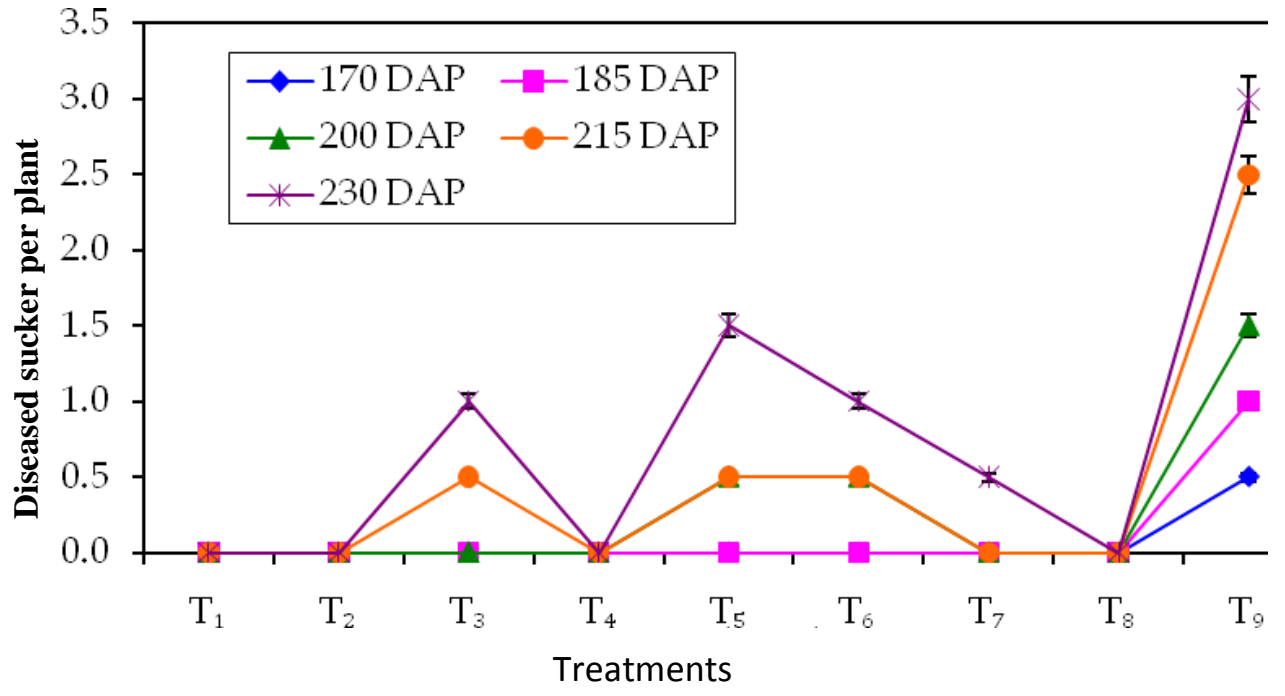

Fig. 3. Effect of Bion and Amistar on diseased sucker per plant of banana var. Amrita Sagarat different days after planting

DAP $=$ Days after planting

$\mathrm{T}_{1}=$ Dipping bottom of sucker for $6 \mathrm{hrs}$ in Bion $(0.005 \%)$ before planting, $\mathrm{T}_{2}=$ Dipping bottom of sucker for $6 \mathrm{hrs}$ in Bion $(0.01 \%)$ before planting, $\mathrm{T}_{3}=$ Spraying Bion $(0.005 \%)$ once on leaves after 80 days of planting, $\mathrm{T}_{4}=$ Spraying Bion $(0.01 \%)$ once on leaves after 80 days of planting, $\mathrm{T}_{5}=$ Spraying Amistar $(0.05 \%)$ once on leaves after 80 days ofplanting, $\mathrm{T}_{6}=$ Spraying Amistar $(0.05 \%)$ once on leaves after 80 and 140 days of planting, $\mathrm{T}_{7}=$ Spraying Bion $(0.005 \%)$ once on leaves and pseudostem after 80 days of planting, $\mathrm{T}_{8}=$ Spraying Bion $(0.01 \%)$ once on leaves and pseudostem after 80 days of planting, $\mathrm{T}_{9}=\mathrm{Control}$ (without chemical). 


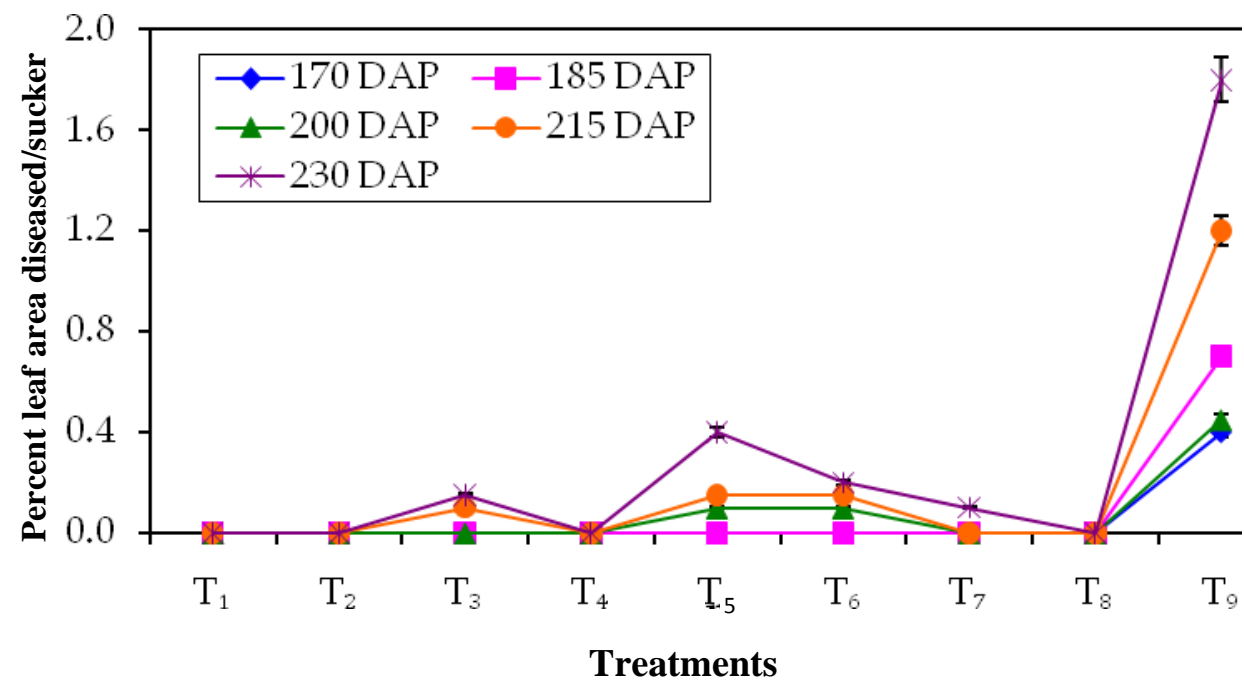

Fig. 4. Effect of Bion and Amistar on percent leaf area diseased/sucker of banana var. Amrita Sagar at different days after planting

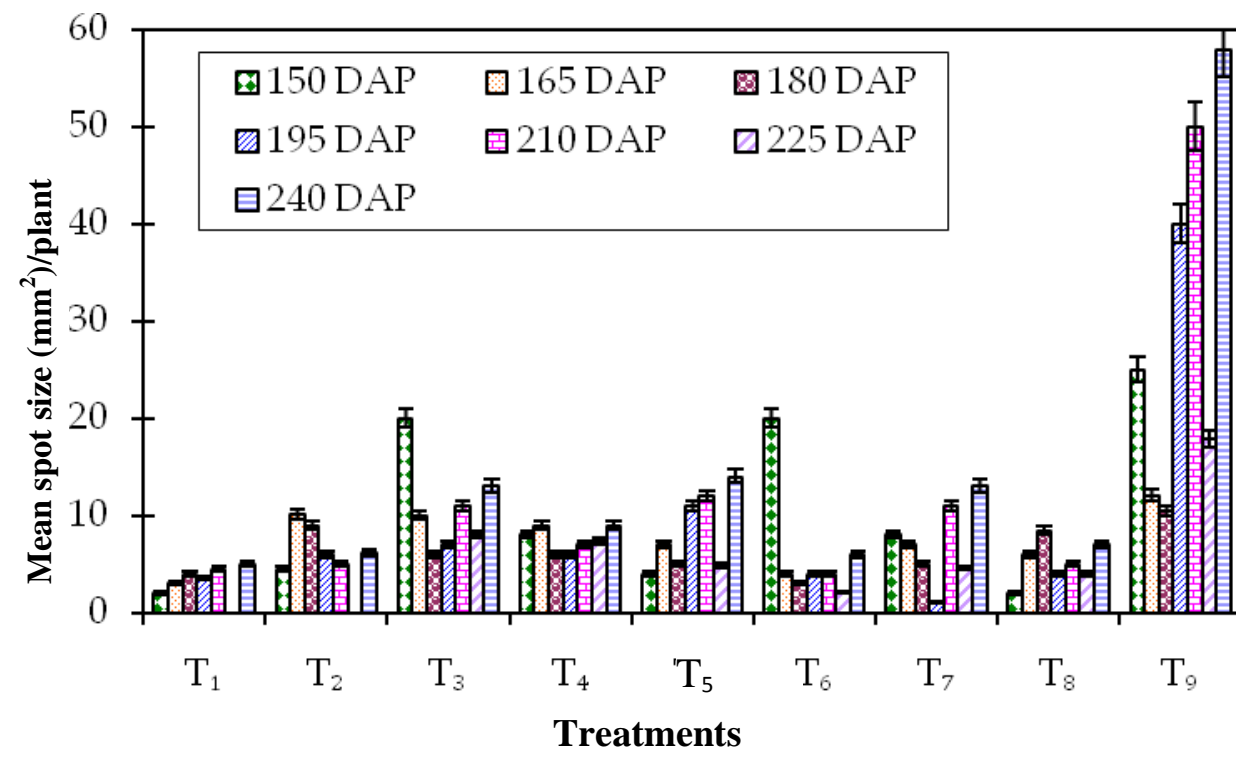

Fig. 5. Effect of Bion and Amistar on mean spot size $\left(\mathrm{mm}^{2}\right) /$ plant of banana var. Amrita Sagar at different days after planting

DAP $=$ Days after planting

$\mathrm{T}_{1}=$ Dipping bottom of sucker for $6 \mathrm{hrs}$ in Bion $(0.005 \%)$ before planting, $\mathrm{T}_{2}=$ Dipping bottom of sucker for $6 \mathrm{hrs}$ in Bion $(0.01 \%)$ before planting, $\mathrm{T}_{3}=$ Spraying Bion $(0.005 \%)$ once on leaves after 80 days of planting, $\mathrm{T}_{4}=$ Spraying Bion $(0.01 \%)$ once on leaves after 80 days of planting, $\mathrm{T}_{5}=$ Spraying Amistar $(0.05 \%)$ once on leaves after 80 days of planting, $\mathrm{T}_{6}=\mathrm{Spraying}$ Amistar $(0.05 \%)$ once on leaves after 80 and 140 days of planting, $\mathrm{T}_{7}=$ Spraying Bion $(0.005 \%)$ once on leaves and pseudostem after 80 days of planting, $\mathrm{T}_{8}=$ Spraying Bion $(0.01 \%)$ once on leaves and pseudostem after 80 days of planting, $\mathrm{T}_{9}=\mathrm{Control}$ (without chemical)

Altogether nine different treatments were used for controlling Cercospora leaf spot of banana variety Amrita Sagar in the field. Bion and Amistar (spray) were found more effective in increasing plant height in banana var. Amrita Sagar. It had been observed that Bion $0.01 \%$ (on leaves, 1 spray) and Amistar @ 0.05\% (on leaves) significantly increased plant height of banana var. Amrita Sagar. On the other hand, Bion@ 0.005\% (dipping bottom of sucker) and Bion@0.01\% (dipping bottom of sucker) significantly decreased plant height of banana var. Amrita Sagar. Number of leaves per plant was significantly higher in Amrita Sagar. Bion and Amistar showed remarkable effect in controlling Cercospora (sigatoka) leaf spot of banana var. Amrita sagar over control. Bion @ 0.005\% and 0.01\% (dipping of bottom of sucker before planting), Bion @ 0.01\% (on leaves, 1 spray) and $0.01 \%$ (on leaves and pseudostem, 1 spray) and Amistar $0.05 \%$ (on leaves, 2 spray) showed significant performance in reducing number of diseased leaf per plant, number of diseased spot per plant, percent 
leaf area $\left(\mathrm{cm}^{2}\right)$ diseased per plant, mean spot size $\left(\mathrm{mm}^{2}\right)$ per plant of banana var. Amrita Sagar.Bion and Amistar both were more effective in banana var. Amrita Sagarat all counting periods to reduce the number of spot per plant as well as size of spots caused by Cercospora (sigatoka) leaf spot compared to the untreated control plants. Perez et al. (2003) reported that acibenzolar-Smethyl (ASM; Bion $50 \mathrm{WG}$ ) a benzothiadiazole (BTH), is a novel compound that resulting in systemic acquired resistance (SAR) in plants to pathogens. ASM treated plants showed fewer Cercospora nicotianae and Alternaria alternata spots than the untreated plants. Pecze and Kurtz (2000) summarized the results of investigations in Hungary since 1997 on the use of the resistance activator Bion $50 \mathrm{WG}$ in various varieties of winter wheat in relation to resistance to several plant diseases. Hossain et. al (2017) reported that application of Bion @ 0.005\% and 0.01\% (dipping before planting), Bion@ @ 0.01\% (on leaves and pseudostem, 1 spray) and Amistar @ 0.05\% (on leaves, 1 spray), Amistar @ $0.05 \%$ (on leaves, 2 spray) showed significant performance in reducing number of diseased leaf/ plant, number of diseased sucker/ plant, percent leaf area (cm2) diseased/ sucker and mean spot size (mm2)/ plant of banana var. Sabri against Cercospora leaf spot.Csosz et al. (1999) reported that Bion $50 \mathrm{WG}$ is a member of a novel class of inducers of systemic acquired resistance that activates gene expression and disease resistance was also effective in banana var. Amrita Sagar to reduce the number of spot per plant. Takacs and Dolej (1998) reported that tomato plants infected by Fusarium oxysporumf.sp. radicis-lycopersici was treated with the plant activator Bion (a product from CIBA GEIGY1 at $0.01 \%-1 \%$. and they observed that treated plants became less infected with the disease than untreated ones, which indicates the importance of systemically acquired resistance in plant protection, not only in cereals but also horticultural crops. Amistar @ 0.05\% (on leaves, 1 spray) and Amistar @0.05\% (on leaves, 2 spray) were effective to reduce percent leaf area diseased per plant of banana var. Sabri. Robak and sobolewski (1997) stated Amistar 250 SC (azoxystrobin) as the most effective fungicide to control plant pathogens which provided levels of disease control equivalent to or better than current commercial standards.

\section{Conclusion}

It is concluded thatbanana infected by Cercosporaleaf spot (sigatoka) (Cercospora musae) may be successfully controlled by Bion or Amistar. Bion (inducer of resistance) and Amistar (new fungicide) can be advocated to our farmers for controlling Cercosporaleaf spot (sigatoka) of banana.

\section{References}

Anonymous, 1976. Banana in West Bengal, Directorate of Agriculture, Govt. of West Bengal.

Cole, D. L.,1999. The efficacy of acibenzolar-S-Methyl, an inducer of systemic acquired resistance, against bacterial and fungal diseases of tobacco. Crop Protection.18(4): 267-273. https://doi.org/10.1016/S0261-2194(99)00026-5

Csosz, L., Tyihak, E. and Manninger, S., 1999. First experience with BION, as a synthetic plant activator. Novenyvedelem. 35(7): 327-334.

FAO., 2001. Quarterly Bulletin of statistics. FAO Quarterly Bulletin of statistics Basic Data Branch, Statistics Division FAO, VialeDelleTerme Caracalla oo100 Rome, Italy. 21 (3/4): 18.

Haque, M.A. 1988. "Kollar Bagan ", Banana Research Project, Bangladesh Agricultural University, Mymensingh. PMCid:PMC1778962

Hossain, I., Akter, M.A, and Mejan, M.M.R,2017. Induction of resistance of Bion andAmister to banana Var. SabriSabriagainstCercospora leaf spot (sigatoka). Bangladesh journal of Plant Pathology. 33 (1\&2): 2128.

Hossain, M.F., 2014. A study of banana production in Bangladesh: Area, yield and major constraints. ARPN: Journal of Agricultural and. Biological.Science., 9: 206-210.

Janczak, C. and Bielecki, W., 1997. Plant activator bion 50 WG: an innovative approach for disease control in cereals. Progress in Plant Protection. 37(2): 297-300.

Khan, M. A. H., Hossain, I. and Ahmad, M. U, 2015. Impact of Weather on Sigatoka Leaf Spot of Banana (Musa spp. L.) and its Ecofriendly Management. A Scientific Journal of Krishi Foundation. 13(2): 44-53.

Pecze, R. and Kurtz, G. 2000. Three years of experience in the application of the "immune" activator Bion $50 \mathrm{WG}$ in winter wheat. Novenyvedelem, 36(2): 79-82.

Perez, L., Rodriguez, M. E., Rodriguez, F., Roson, C., 2003. Efficacy of acibenzolar-S-methyl, an inducer of systemic acquired resistance against tobacco blue mould caused by Peronosporahyoscyamif.sp. tabacina. Crop Protection, 22(2): 405-413. https://doi.org/10.1016/S0261-2194(02)00198-9

Robak, J. and Sobolewski, J., 1997. New fungicides and possibility for their use in complex diseases control on vegetables.Progress in Plant Protection. 37(2):350-353.

Takacs, A. and Dolej, S., 1998. The effect of the resistance activator. "BION" on the relationship Fusarium oxysporumf. sp. radicis-lycopersici tomato. Novenyvedelem. 34(5): 257-259.

Thammaiah, N. and Shirol, A. M., 2013. Management of sigatoka leaf spot Disease of banana with oil based Formulations. International Journal of Agricltural Sciences and Veterinary Medicine. 1(3): 95-105. 